\title{
REVIEW
}

\section{Scaling of fecundity, growth and development in marine planktonic copepods}

\author{
Thomas Kiørboe, Marina Sabatini * \\ Danish Institute for Fisheries and Marine Research, Charlottenlund Castle, DK-2920 Charlottenlund, Denmark
}

\begin{abstract}
We compiled information from the literature on female and egg sizes and maximum egg production, growth and developmental rates in marine planktonic copepods. While specific growth and developmental rates are invariant with body mass, weight-specific fecundity scales with female body mass ${ }^{-0.26}$ in both broadcast-spawning and egg-carrying copepods. Egg sizes increase with female size and, consequently, egg production rates (no. of eggs $\mathrm{q}^{-1} \mathrm{~d}^{-1}$ ) are constant with size. Developmental rates were similar among egg-carrying and broadcast-spawning copepods, but the latter grow faster by 30 to $50 \%$ and have weight-specific fecundities that are 2.5 times and egg production rates that are 7.5 times those of the former. Nauplii develop faster (by a factor of 2) but grow slower (by 20 to $40 \%$ ) than copepodites in both spawning types. The main demographic implications of these findings are (1) that mortality is independent of body mass per se, (2) that sac spawners suffer higher overall mortality rates than broadcast spawners and (3) nauplii suffer higher mortality than copepodids.
\end{abstract}

KEY WORDS: Copepods $\cdot$ Allometry $\cdot$ Fecundity $\cdot$ Growth $\cdot$ Development

\section{INTRODUCTION}

Vital rates (e.g. feeding, metabolism, growth) of both animals and plants typically scale nonlinearly with body mass and are often described by an allometric relation of the type:

or

$$
\begin{aligned}
& V=a W^{b} \\
& V=a W^{b-1}
\end{aligned}
$$

where $V$ and $v$ are the absolute and weight-specific vital rate in question, and $a$ and $b$ are constants. The exponent $b$ is frequently close to 0.67 , and $b-1$ thus near -0.33 (Zeuthen 1953, Hemmingsen 1960, Banse 1982).

The present study was prompted by the following observations and considerations (Kiørboe \& Sabatini 1994): weight-specific juvenile growth and development times in planktonic copepods appear to be inde-

\footnotetext{
- Present address: Instituto Nacional de Investigacion y Desarollo Pesquero, CC. No. 175 Playa Grande, 7600 Mar del Plata, Argentina
}

pendent of body mass (i.e. $b=1$ ) (Huntley \& Lopez 1992), whereas the size of eggs scale with body mass raised to an exponent of ca 0.65 (Kiørboe \& Sabatini 1994). If weight-specific female egg production scales with body mass the same way as juvenile growth, egg production in terms of no. of eggs $\circ^{-1} \mathrm{~d}^{-1}$ is bound to increase with body mass (proportional to ca $W^{10 / 0.65}=$ $W^{0.35}$ ). This, in turn, implies that instantaneous mortality rates should increase with increasing body mass in copepods, because the eggs produced by 1 female should, on average, result in only 1 female surviving to the next generation - otherwise the population would either go extinct or the population size would increase infinitely. This is a counterintuitive and uncomfortable observation, and Kiørboe \& Sabatini (1994) consequently called for a thorough examination of existing data on the scaling of fecundity, growth and developmental rates in copepods.

The purpose of this study is to review and report observations on fecundity, growth and development in planktonic copepods and to examine the demographic implications hereof. 


\section{MATERIAL AND METHODS}

We are looking for patterns that transcend species differences. We are aware that there are differences in specific growth and fecundity rates between species. but we expect that the species effect is secondary to body mass scaling effects when a sufficiently large range in body masses is considered, as has been shown for the vital rates of other (even more diverse) groups of organisms, be it plants (e.g. Nielsen \& Sand-Jensen 1990) or animals (e.g. Fenchel 1974, Banse 1982). Yet the nature of the data we are to report forced us to classify planktonic copepods into sac-spawning (egg-carrying) and broadcast-spawning (free) types. Kiørboe \& Sabatini (1994) showed that fecundity rates and egg hatching times differ substantially between these 2 types, and that the difference recurs across taxonomic groups (e.g. calanoid and cyclopoid copepods). We therefore retain some degree of type-classification in the data we report here. Also, Oncaeatidae, although pelagic, are not really planktonic. Evidence is accumulating that these copepods occur mainly associated with large marine snow aggregates, and that their ecology and lifecycle strategy therefore differs radically from that of truly planktonic copepods (Paffenhöfer 1993, Dagg 1994). We therefore also separate this group out in our data presentation.

Our main data source is observations reported in the literature. We based our literature search mainly on the electronic version of Aquatic Sciences and Fisheries Abstract (1978 onwards). Below we describe how data were selected and transformed.

We compiled only information on marine pelagic copepods, and only average maximum (in contrast to absolute maximum) rates measured experimentally in the laboratory at temperatures ranging between 10 and $20^{\circ} \mathrm{C}$ and at saturating food concentrations were considered in this presentation.

The rates obtained at the experimental temperatures were converted to the rate at a temperature of $15^{\circ} \mathrm{C}$ by assuming a $Q_{10}=3.0$ for growth, developmental and egg production rates. This value of $Q_{10}$ was derived from the exponential temperature coefficient (0.111) obtained by Huntley \& Lopez (1992) in their review of copepod growth versus temperature in the range -5 to $25^{\circ} \mathrm{C}$. About the same $Q_{10}$ value has been reported also for individual copepod species: Eurytemora affinis: 3.1 and $E$. herdmani: 3.0 in the range 2 to $23.5^{\circ} \mathrm{C}$ (Katona 1970); Oithona nana: 3.06 (Haq 1965); Calanus glacialis: 2.9 in the range 4 to $13.5^{\circ} \mathrm{C}$ (Hirche \& Bohrer 1987); O. similis: 3.1 in the range 9 to $14^{\circ} \mathrm{C}$ (Sabatini \& Kiørboe 1994, calculated from Eaton 1971). When rates were reported for several experimental temperatures in the same study we used only that rate measured closest to $15^{\circ} \mathrm{C}$.
Whenever possible we avoided combining information from several studies, e.g. to calculate weightspecific egg production from the egg production rate measured in one study and female body weight of the same species measured in another. However, this was frequently necessary. In those cases we used averages of, for example, female body weight measured in all other available studies (Appendix 1).

We selected carbon and days as our common units. Body weights reported as dry wt or ash-free dry weight (AFDW) were converted to carbon assuming $0.4 \mu \mathrm{g} \mathrm{C}$

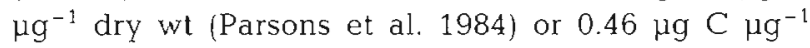
AFDW (Paffenhöfer \& Harris 1976). Egg carbon was estimated from egg size by assuming $0.14 \times 10^{-6} \mu \mathrm{g} \mathrm{C}$ $\mathrm{um}^{-3}$ (Kiørboe et al. 1985, Huntley \& Lopez 1992) if not reported in the original paper. All temperaturecorrected and carbon-converted raw data have been tabulated in Appendices 1 to 6.

Egg production rates (Appendix 2). In most cases egg production rates were reported as eggs $\wp^{-1} \mathrm{~d}^{-1}$, in some cases also as weight-specific rates. When weightspecific rates were not available in the original report they were estimated from no. of eggs $q^{-1} \mathrm{~d}^{-1}$ and reported (or calculated) egg and female carbon contents.

Developmental rates (Appendix 3) and development times (Appendix 4). Information about copepod development is available in the literature as total development time, as stage durations, or as cumulative development time of stages, from which stage durations can be estimated. Total development times have been reported somewhat differently in the various reports, i.e. as time from egg to $\mathrm{C} 6$ or time from N1 to C6. The way used to calculate the cumulative development times also differs among papers; thus, 'mean time of stage' yields estimates that are ca $10 \%$ faster than 'median development time' (Peterson \& Painting 1990). In Appendices $3 \& 4$ we have specified the type of calculation. We did not attempt to correct for these variations, since it does not bias our results, but only introduces some noise. We estimated development rates by averaging the reciprocal of the single-stage durations reported in the original papers. Since 'isochronality' (sensu Landry 1983) is not a general 'rule' among copepods (Hart 1990), average developmental rates were calculated separately for nauplii (N1 to N6), copepodids (C1 to $C 6$ ) and late copepodids (C4 or $\mathrm{C} 5$ to $\mathrm{C} 6$ ). When development rates of males and females were reported separately we used only the female rate.

Weight-specific growth rates (Appendices 5 \& 6). Most of the reported weight-specific growth rates were estimated in the original papers from the slope of the regression of body weight versus time, or weight of the stages versus development time. With a few exceptions weight (carbon, dry wt or AFDW) was obtained 
from length-weight relationships. We calculated weight-specific growth rates for nauplii (N1 to N6), copepodids ( $\mathrm{C} 1$ to $\mathrm{C} 6$ ) and late copepodids ( $\mathrm{C} 4$ or $\mathrm{C} 5$ to C6) separately by averaging the single-stage rates determined experimentally.

We also estimated weight-specific growth rates $(g)$ indirectly from the approximate relationship

$$
g=\ln \left(W_{Q} / W_{\text {egg }}\right) / D
$$

where $W_{Q}$ and $W_{\text {egg }}$ are the carbon content of females and eggs, respectively and $D$ is the development time (Appendix 6). This provides an independent set of growth rate estimates.

\section{RESULTS}

\section{Egg size and egg hatching time}

Data on egg sizes and egg hatching times in planktonic copepods have been reviewed by Kiorboe \& Sabatini (1994) but here we complement the data they compiled. Egg sizes increase with female body mass in both egg-carrying and broadcast-spawning copepods, but the weight exponent differs significantly between the 2 groups, 0.93 and 0.62 , respectively (Table 1 , Fig. 1). For the egg-carrying copepods the weight exponent is not significantly different from 1.0 , and egg

Table 1. Regression parameters and determination coefficients $\left(\mathrm{r}^{2}\right)$ for the relations shown in Figs. 1 to 7 . n: number of observations. Significance levels are: $p<5 \%, \cdots p<1 \%, \cdots p<0.1 \%$, ns: not significant

\begin{tabular}{|c|c|c|c|c|c|c|c|c|}
\hline Dependent variable & $\begin{array}{l}\text { lndependent } \\
\text { variable }\end{array}$ & $\begin{array}{l}\text { Sac- (S) or broad- } \\
\text { cast (B) spawners }\end{array}$ & $\begin{array}{l}\text { Intercept } \\
\quad \pm \mathrm{SE}\end{array}$ & $\begin{array}{l}\text { Slope } \\
\pm \mathrm{SE}\end{array}$ & $\mathrm{n}$ & $r^{2}$ & $\mathrm{p}$ & Fig \\
\hline \multirow[t]{3}{*}{$\log (\mathrm{Egg}$ size $), \mu g \mathrm{C}$} & \multirow[t]{5}{*}{$\log (\rho$ size $), \mu g C$} & $\mathrm{~s}$ & $\begin{array}{r}-1.841 \\
0.098\end{array}$ & $\begin{array}{l}0.930 \\
0.084\end{array}$ & 21 & 0.87 & $\cdots$ & \\
\hline & & B & $\begin{array}{r}-1.859 \\
0.100\end{array}$ & $\begin{array}{l}0.621 \\
0.057\end{array}$ & 41 & 0.75 & $\cdots$ & \\
\hline & & $\mathrm{B}+\mathrm{S}$ & $\begin{array}{r}-1.825 \\
0.080\end{array}$ & $\begin{array}{l}0.662 \\
0.051\end{array}$ & 62 & 0.74 & $\cdots$ & \\
\hline \multirow[t]{2}{*}{$\log \left(\right.$ Fecundity),$d^{-1}$} & & $s$ & $\begin{array}{r}-0.850 \\
0.066\end{array}$ & $\begin{array}{r}-0.260 \\
0.058\end{array}$ & 10 & 0.72 & $\cdots$ & \multirow[t]{2}{*}{2} \\
\hline & & $\mathrm{B}$ & $\begin{array}{r}-0.474 \\
0.079\end{array}$ & $\begin{array}{r}-0.262 \\
0.067\end{array}$ & 35 & 0.32 & $\cdots$ & \\
\hline \multirow[t]{2}{*}{$\begin{array}{l}\text { Log(Egg prod. rate), } \\
\text { no. of eggs } Q^{-1} \mathrm{~d}^{-1}\end{array}$} & \multirow[t]{2}{*}{$\log (\varphi$ size $), \mu \mathrm{g} C$} & $\mathrm{~S}$ & $\begin{array}{l}0.803 \\
0.069\end{array}$ & $\begin{array}{r}-0.128 \\
0.060\end{array}$ & 10 & 0.36 & ns & \multirow[t]{2}{*}{3} \\
\hline & & $\mathrm{B}$ & $\begin{array}{l}1.386 \\
0.080\end{array}$ & $\begin{array}{l}0.141 \\
0.069\end{array}$ & 35 & 0.11 & ns & \\
\hline $\begin{array}{l}\text { Log(Development time), } \\
d\end{array}$ & Log(o size), $\mu \mathrm{g} \mathrm{C}$ & $B+S$ & $\begin{array}{l}1.383 \\
0.030\end{array}$ & $\begin{array}{r}-0.008 \\
0.030\end{array}$ & 31 & 0.003 & ns & 4 \\
\hline \multirow[t]{3}{*}{$\begin{array}{l}\text { Log(Development rate) } \\
\text { stages } h^{-1}\end{array}$} & \multirow[t]{3}{*}{$\log (q$ size), $\mu \mathrm{g} C$} & $\begin{array}{c}\mathrm{B}+\mathrm{S} \\
\text { Nauplii }\end{array}$ & $\begin{array}{r}-1.558 \\
0.082\end{array}$ & $\begin{array}{l}0.071 \\
0.061\end{array}$ & 22 & 0.06 & ns & $5 \mathrm{a}$ \\
\hline & & $\begin{array}{c}\text { B+S } \\
\text { Copepodids }\end{array}$ & $\begin{array}{r}-1.674 \\
0.054\end{array}$ & $\begin{array}{r}-0.066 \\
0.043\end{array}$ & 26 & 0.09 & ns & $5 b$ \\
\hline & & $\begin{array}{c}\mathrm{B}+\mathrm{S} \\
\mathrm{C} 4 / 5 \text { to Adult }\end{array}$ & $\begin{array}{r}-1.865 \\
0.067\end{array}$ & $\begin{array}{r}-0.061 \\
0.048\end{array}$ & 23 & 0.07 & ns & $5 c$ \\
\hline \multirow[t]{6}{*}{$\begin{array}{l}\log (\text { Growth rate }) \\
\mathrm{d}^{-1}\end{array}$} & \multirow[t]{6}{*}{$\log (\rho$ size) $\mu \lg C$} & $\begin{array}{c}\mathrm{S} \\
\text { Nauplii }\end{array}$ & $\begin{array}{r}-0.719 \\
0.089\end{array}$ & $\begin{array}{r}-0.032 \\
0.114\end{array}$ & 4 & 0.04 & ns & \multirow[t]{2}{*}{$6 a$} \\
\hline & & $\begin{array}{c}\text { B } \\
\text { Nauplii }\end{array}$ & $\begin{array}{r}-0.661 \\
0.072\end{array}$ & $\begin{array}{l}0.091 \\
0.061\end{array}$ & 14 & 0.16 & ns & \\
\hline & & $\begin{array}{c}\text { S } \\
\text { Copepodids }\end{array}$ & $\begin{array}{r}-0.637 \\
0.087\end{array}$ & $\begin{array}{l}0.052 \\
0.087\end{array}$ & 6 & 0.05 & ns & \multirow[t]{2}{*}{$6 \mathrm{~b}$} \\
\hline & & $\begin{array}{c}\text { B } \\
\text { Copepodids }\end{array}$ & $\begin{array}{r}-0.474 \\
0.070\end{array}$ & $\begin{array}{r}-0.008 \\
0.054\end{array}$ & 16 & 0.001 & ns & \\
\hline & & $\begin{array}{c}\mathrm{S} \\
\mathrm{C} 4 / 5 \text { to Adult }\end{array}$ & $\begin{array}{r}-1.046 \\
0.040\end{array}$ & $\begin{array}{l}0.394 \\
0.051\end{array}$ & 5 & 0.95 & 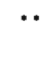 & $6 c$ \\
\hline & & $\begin{array}{c}\text { B } \\
\text { C4/5 to Adult }\end{array}$ & $\begin{array}{r}-0.278 \\
0.118\end{array}$ & $\begin{array}{r}-0.249 \\
0.081\end{array}$ & 11 & 0.51 & $\cdot$ & \\
\hline \multirow[t]{2}{*}{$\begin{array}{l}\text { Log }(\text { Growth rate } \\
\left.=\ln \left(W_{\odot} / W_{\text {egg }}\right) / D\right) \cdot \mathrm{d}^{-1}\end{array}$} & \multirow[t]{2}{*}{$\log (9$ size $), \mu g C$} & $\mathrm{~S}$ & $\begin{array}{r}-0.803 \\
0.100\end{array}$ & $\begin{array}{l}0.126 \\
0.100\end{array}$ & 6 & 0.19 & ns & \multirow[t]{2}{*}{7} \\
\hline & & $B$ & $\begin{array}{r}-0.584 \\
0.058\end{array}$ & $\begin{array}{r}-0.011 \\
0.039\end{array}$ & 14 & 0.007 & $\mathrm{~ns}$ & \\
\hline
\end{tabular}




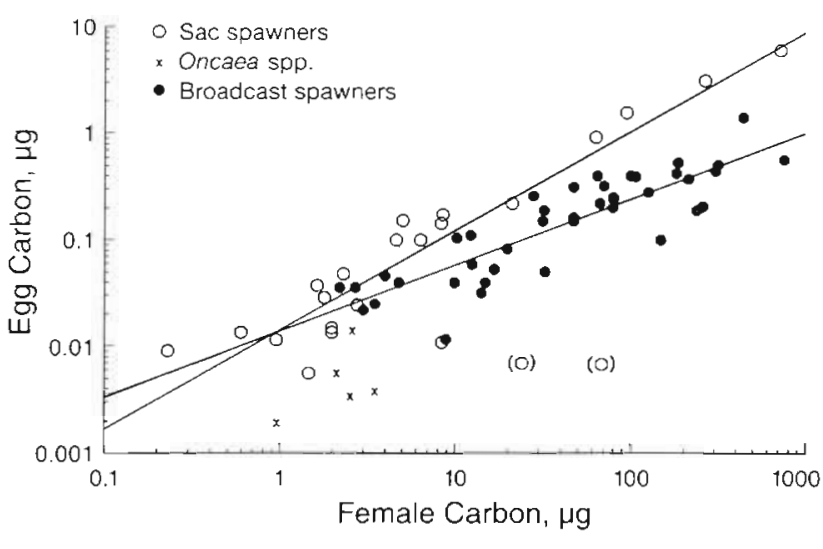

Fig. 1. Egg size as a function of female body mass in sac- and broadcast-spawning marine pelagic copepods. Observations in parentheses as well as for Oncaea sp. not included in regressions. Regression statistics are given in Table 1

size thus appears to be approximately proportional to female size in this group. Eggs of oncaeatid copepods are significantly smaller than eggs of other cyclopoid and calanoid copepods, but the range in female sizes was insufficient to calculate a regression.

Egg hatching times are independent of female size $\left(\mathrm{r}^{2}=0.26, \mathrm{n}=11\right.$ and $\mathrm{r}^{2}=0.01, \mathrm{n}=17$ for sac- and broadcast spawners respectively) and of egg size $\left(\mathrm{r}^{2}=\right.$ $0.45, n=8$ and $r^{2}=0.11, n=18$, respectively) but differ significantly between sac- and broadcast spawners ( $\bar{x}$ $=3.88 \pm 2.32$ and $1.51 \pm 0.59 \mathrm{~d}$, respectively, at $15^{\circ} \mathrm{C}$ ).

\section{Weight-specific fecundity and egg production rate}

Weight-specific fecundity rates decline with female body size and scale with body mass raised to an exponent of -0.26 for both sac-and broadcast spawners (i.e. $b=0.74$; Fig. 2, Table 1). The intercepts, however, differ significantly $(p<1 \%)$, and broadcast spawners have weight-specific fecundities that are on average ca 2.5 times the weight-specific fecundity of sac spawners.

Because weight-specific fecundity and weight-specific egg sizes in broadcast spawners scale with female body mass in almost the same way (exponents -0.26 and -0.38 ) it is not surprising that egg production in terms of no. of eggs $\rho^{-1} \mathrm{~d}^{-1}$ is size independent (Fig. 3, Table 1). In sac spawners egg production decreases slightly with female size, but the decrease is not statistically significant. Thus, small and large copepods have similar daily egg production rates. However, broadcast spawners produce on average 7.5 times as many eggs as sac spawners, with overall average maximum egg production rates of $40 \pm 23$ and $5.3 \pm$ 2.2 eggs ${ }^{-1} \mathrm{~d}^{-1}$ at $15^{\circ} \mathrm{C}$.

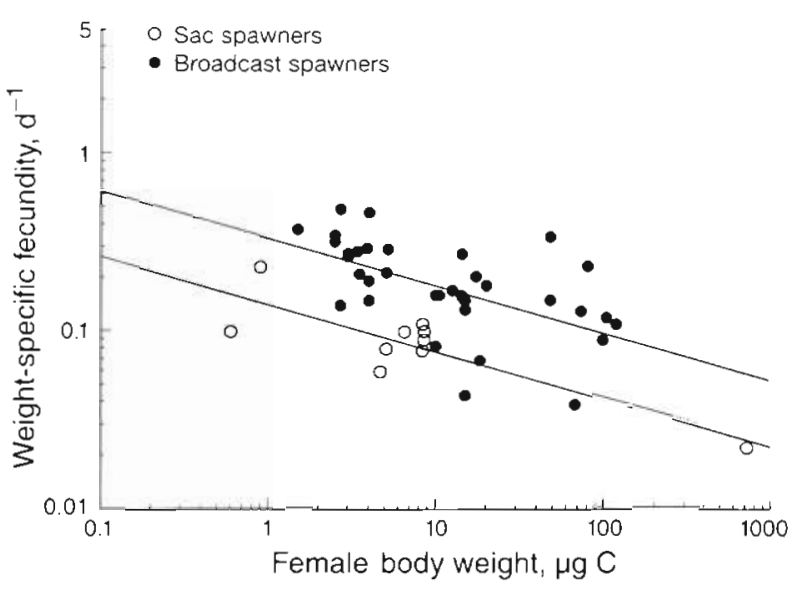

Fig. 2. Weight-specific fecundity ( $\mu \mathrm{g} C \mu \mathrm{g}^{-1} \mathrm{C} \mathrm{d}^{-1}$ ) as a function of female body weight in sac- and broadcast-spawning marine pelagic copepods. Regression statistics are given in Table 1

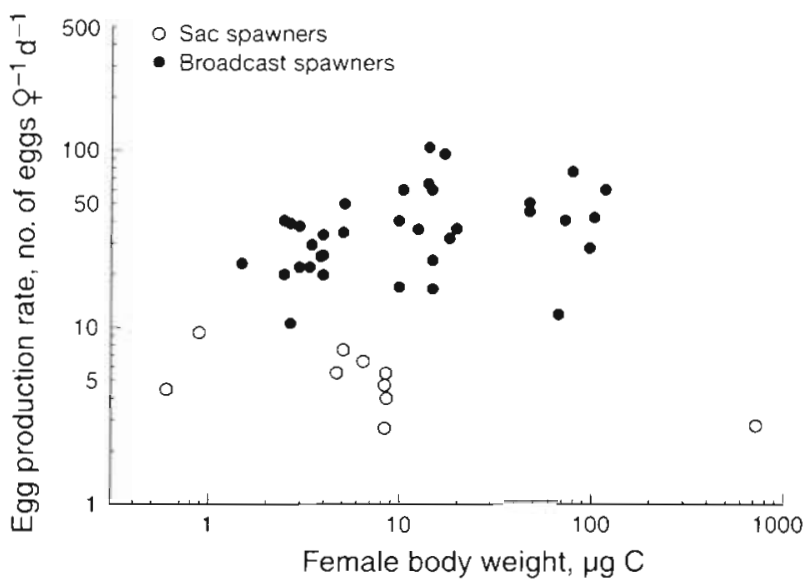

Fig. 3. Egg production rate as a function of female body mass in sac- and broadcast-spawning copepods

The 7.5-fold difference in the number of eggs produced per day and the 2.5-fold difference in weightspecific fecundity between broadcast- and sac spawners suggests that, on average, carried eggs are ca 3 times bigger than freely spawned eggs. This difference is most pronounced for the larger copepods, and less pronounced for the smaller ones (Fig. 1).

\section{Development time and development rate}

Development time, i.e. the time from egg to adult, is independent of female size (Fig. 4, Table 1), and also does not differ significantly between sac- and broadcast spawners ( $p>5 \%$, t-test; Table 2).

Developmental rates calculated seperately for nauplii, copepodids and late copepodid stages (C4 or 


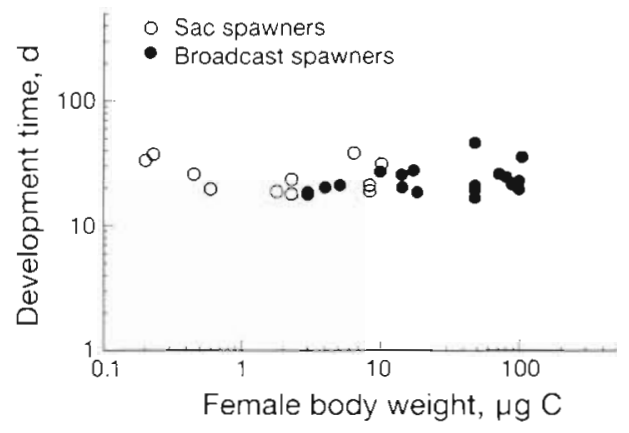

Fig. 4. Development time as a function of female body mass in sac- and broadcast-spawning copepods

C5 to adults) are all independent of female size and also do not differ significantly between sac-and broadcast-spawners (Fig. 5, Table 2). However, for both groups developmental rates slow down as development progresses, and are highest for nauplii and slowest for late copepodids (Table 2); these differences are statistically significant (ANOVA, $\mathrm{p}<0.1 \%$ )

\section{Growth rate}

Weight-specific growth rates determined experimentally are independent of female size, both in nauplii, copepodids and late copepodid stages (Fig. 6). Growth rates estimated indirectly as $\ln \left(W_{o} / W_{\text {egg }}\right) / D$, where $W_{Q}, W_{\text {egg }}$ and $D$ are weights of females and eggs and developmental times, respectively, are also independent of female size (Fig. 7. Table 1).

Average growth rates vary significantly and consistently between sac- and broadcast spawners, and between nauplii, copepodids and late copepodids (Table 3). Broadcast spawners grow 30 to $50 \%$ faster than sac spawners and copepodids grow ca $25 \%$ faster than nauplii and late copepodids in both spawning types. Thus, nauplii develop faster but grow slower than copepodids.

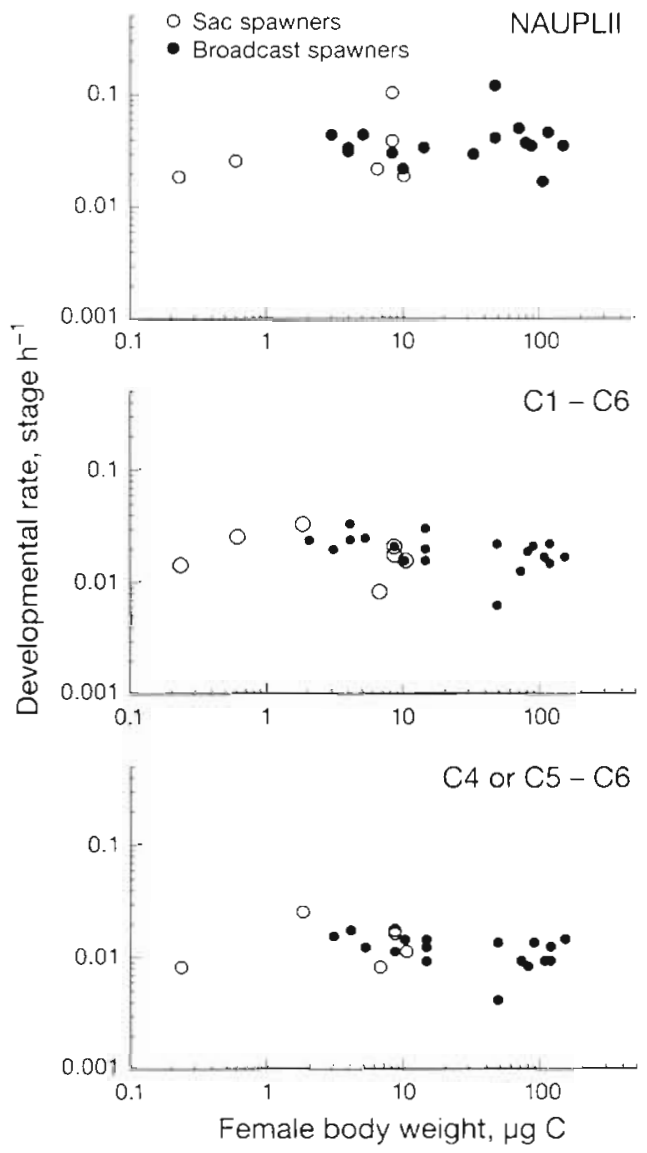

Fig. 5. Developmental rate as a function of female body weight in sac- and broadcast-spawning copepods; plotted separately for nauplii (egg or N1 to N6), copepodids (C1 to C6), and late copepodids (C4 or C5 to adult)

to 0.75$)$ as demonstrated by the extensive $(n=550)$ laboratory data compiled by Peters \& Downing (1984) and with the scaling of metabolic rates in aquatic crustaceans, including planktonic copepods $(b \approx 0.8$; e.g. Ivleva 1980, Vidal \& Whitledge 1982). Given this background it is surprising that juvenile growth rate

\section{DISCUSSION}

\section{Allometry}

The allometric scaling of copepod fecundity with female body mass $(b=$ $0.74)$ for both sac- and broadcast spawners accords with our general expectation (e.g. Zeuthen 1953, Hemmingsen 1960, Fenchel 1974 Banse 1982). It is also consistent with the allometric scaling of feeding rates in marine calanoid copepods $(b=0.37$
Table 2. Total development time and developmental rate of nauplii, copepodids ( $\mathrm{C} 1$ to $\mathrm{C} 6$ ) and late copepodids (C4/5 to $\mathrm{C} 6$ ) (average $\pm \mathrm{SD}$ ) in sac spawners, broadcast spawners and in both groups considered together at $15^{\circ} \mathrm{C}$. n: no. of observations

\begin{tabular}{|lcccc|}
\hline & Development & \multicolumn{3}{c|}{ Developmental rate $\left(\right.$ stage $\mathrm{h}^{-1}$ ) } \\
& time $(\mathrm{d})$ & Nauplii & Copepodids & C4/C5 to Adults \\
\hline Sac & $25.71 \pm 7.52$ & $0.036 \pm 0.032$ & $0.019 \pm 0.008$ & $0.014 \pm 0.007$ \\
spawners & $\mathrm{n}=12$ & $\mathrm{n}=6$ & $\mathrm{n}=7$ & $\mathrm{n}=6$ \\
Broadcast & $23.82 \pm 7.14$ & $0.038 \pm 0.021$ & $0.019 \pm 0.006$ & $0.012 \pm 0.003$ \\
spawners & $\mathrm{n}=19$ & $\mathrm{n}=16$ & $\mathrm{n}=19$ & $\mathrm{n}=17$ \\
$\begin{array}{l}\text { Sac }+ \\
\text { broadcast }\end{array}$ & $24.55 \pm 7.23$ & $0.038 \pm 0.024$ & $0.019 \pm 0.006$ & $0.012 \pm 0.004$ \\
& $\mathrm{n}=31$ & $\mathrm{n}=22$ & $\mathrm{n}=26$ & $\mathrm{n}=23$ \\
\hline
\end{tabular}




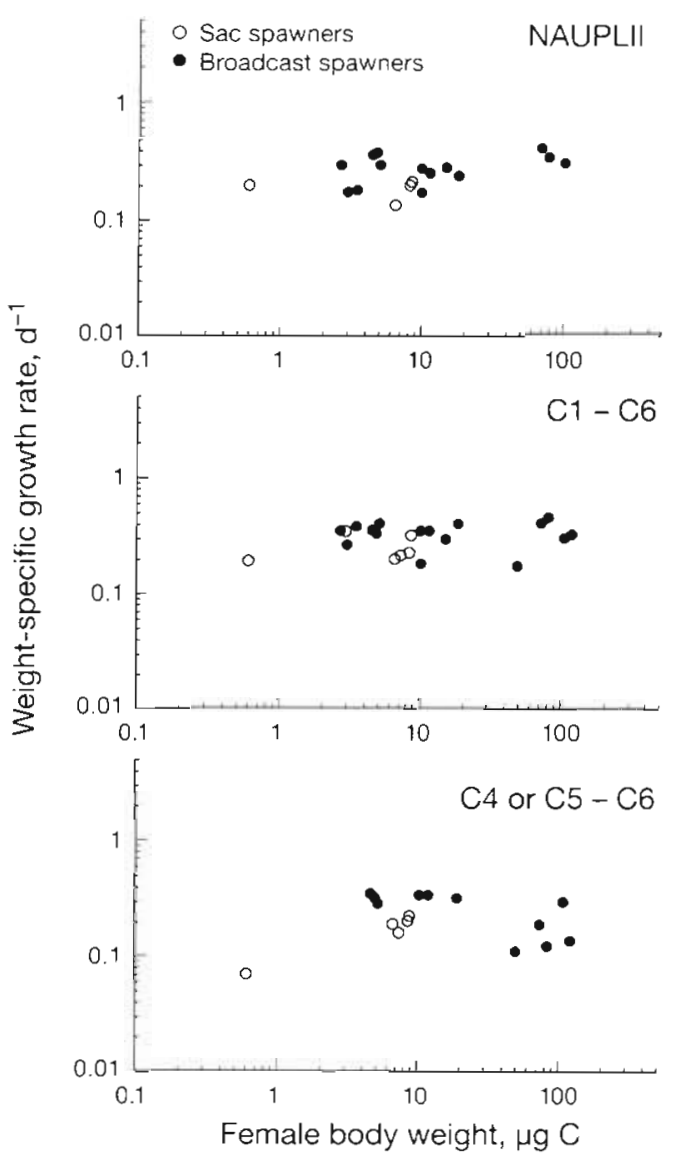

Fig. 6. Weight-specific growth rate $\left(\mu \mathrm{g} \mathrm{C} \mu \mathrm{g}^{-1} \mathrm{C} \mathrm{d}^{-1}\right)$ as a function of female body weight in sac- and broadcastspawning copepods; plotted separately for nauplii, copepodids and late copepodids

appears to be directly proportional to body mass and specific growth rate, thus, independent of size (i.e. $b=$ 1). Our data clearly demonstrate this, and the same result was reached by previous authors on less extensive data sets (Huntley \& Lopez 1992). We have no suggestions as to the physiological basis of this discrep-

Table 3. Measured weight-specific growth rates of nauplii, copepodids (C1 to C6) and late copepodids (C4/5 to $C 6$ ) and total growth rate estimated from egg and female carbon contents ( $W_{\text {egg }}$ and $W_{\odot}$ ) and development times $(D)$ in sac spawners, broadcast spawners and in both groups considered together at $15^{\circ} \mathrm{C}$. Average $\pm \mathrm{SD}$ is shown; $\mathrm{n}$ : no. of observations

\begin{tabular}{|ccccc|}
\hline \multicolumn{4}{c}{ Measured growth rate $\left(\mathrm{d}^{-1}\right)$} & $\ln \left(W_{\%} / W_{\text {egg }}\right) / D$ \\
& Naupli & Copepodids & Total & \\
\hline $\begin{array}{l}\text { Sac } \\
\text { spawners }\end{array}$ & $0.185 \pm 0.035$ & $0.255 \pm 0.066$ & 0.220 & $0.182 \pm 0.038$ \\
Broadcast & $0.282 \pm 0$ & $n=6$ & & $n=4$ \\
spawners & $n=14$ & $0.339 \pm 0.078$ & 0.311 & $0.254 \pm 0.047$ \\
$\begin{array}{l}\text { Sac }+ \\
\text { broadicast }\end{array}$ & $0.261 \pm 0.079$ & $0.316 \pm 0.083$ & 0.289 & $0.236 \pm 0.054$ \\
& $n=18$ & $n=22$ & & $n=16$
\end{tabular}

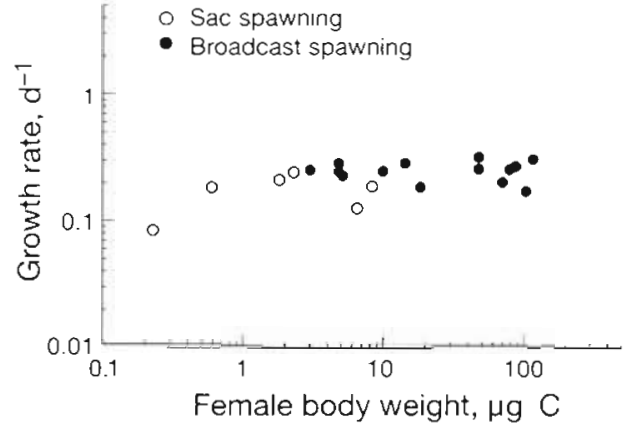

Fig. 7. Weight-specific growth rate $\left(\mu \mathrm{g} \mathrm{C} \mu g^{-1} \mathrm{C} \mathrm{d}^{-1}\right)$ calculated from carbon contents of eggs $\left(W_{\text {egg }}\right)$ and females $\left(W_{Q}\right)$ and developmental time $\left[\ln \left(W_{Q} / W_{\text {egg }}\right) / D\right]$ as a function of female body weight in sac-and broadcast-spawning copepods

ancy between the mass dependency of juvenile and female growth rates.

Because of the approximate relation $g=\ln \left(W_{0}\right)$ $\left.W_{\text {egg }}\right) / D$, it may at first appear inconsistent that both $g$ and $D$ are size independent in broadcast spawners while at the same time $W_{\mathrm{q}} / W_{\text {egg }}$ depend on female size (scale with $W_{\varphi}^{0.38}$ ). Replacing $W_{\varphi} / W_{\text {egg }}$ with $a W_{\varphi}^{0.38}$ in Eq. (3), where $a$ is a constant, yields:

$$
g=\left(\ln a+0.38 \ln W_{Q}\right) / D=(\ln a) D+(0.38 / D) \ln W_{\text {o }}
$$

i.e. $g$ is bound to increase with body mass if $D$ is constant, as also noted by Frost (1980). However, at $15^{\circ} \mathrm{C}$ the slope of increase is only $0.38 / D \approx 0.015$ (because $\mathrm{D} \approx 25 \mathrm{~d}_{\mathrm{i}}$ Table 2 ), and the relation, therefore, too weak to detect with noisy data. In fact, for broadcast spawners regressions of $g$ vs $\ln W_{\mathrm{o}}$ in both nauplii and copepodids yield slightly positive slopes that do not differ significantly from 0.015 (nor from 0). These observations and considerations suggest that weight-specific juvenile growth in copepods is independent of or, if anything, increases slightly with body mass.

\section{Demographic implications}

Size dependency of copepod mortality rates

The egg production rate, mortality and developmental time of a population together describes its population dynamics. The net reproductive rate, $R_{0}$, i.e. the number of offspring per female that survives until the next generation, is given by:

$$
R_{0}=\int l_{x} m_{x} \mathrm{~d} x
$$

where $x$ is the age, $l_{x}$ is the age-specific 


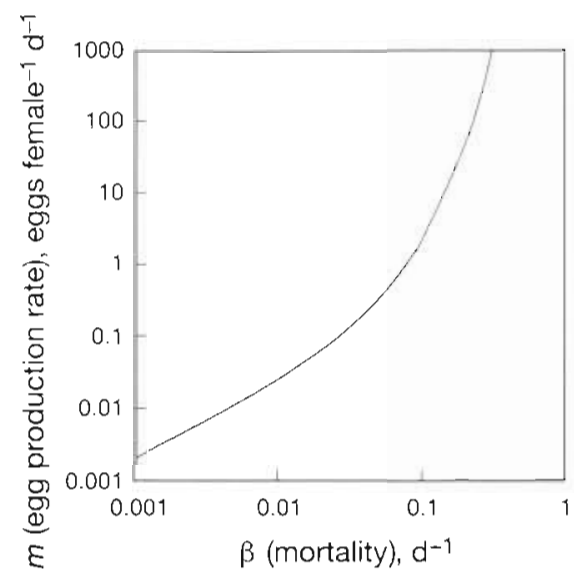

Fig. 8. Theoretical relationship between egg production rate and mortality rate for a hypothetical copepod population in steady state, assuming a $1: 1$ sex ratio and a developmental time of $25 \mathrm{~d}$

survival and $m_{x}$ the age-specific egg production rate. For simplicity and for the purpose of the following considerations we will initially assume that the mortality rate, $\beta\left(\mathrm{d}^{-1}\right)$, is age independent, and that the egg production rate is constant for $x \geq D$ and zero for $x<D$. It can then be shown that (Kiørboe \& Sabatini 1994):

$$
R_{0}=(m / \beta) \mathrm{e}^{-\beta D},
$$

where $D$ is the developmental time. For the population to be maintained, $R_{0}$ should on average be equal to 2 (assuming a 1:1 sex-ratio); thus

$$
m=2 \beta \mathrm{e}^{\beta D} \text {. }
$$

In this notation $m$ is the realized egg production rate, not the maximum one. Fig. 8 is a graphical presentation of Eq. (7) for a hypothetical copepod population in steady state at $15^{\circ} \mathrm{C}$ and with a development time of 25 d. If we assume that the realized egg production rate, like the maximum one, is size independent, it follows that $\beta$, the mortality coefficient, is size independent. Although the fecundity of planktonic copepods is often considerably less than maximum in the field, likely due to food limitation (reviewed by Kiørboe 1991), there is no a priori reason to believe that the degree of food limitation should on average be different between small and large copepods. This is because the food size spectra of copepods can be described by log-normal distributions that have approximately equal variances (widths) between species (Berggreen et al. 1988). In the average pelagic environment the biomass of particulate matter appears to be approximately constant in equal, logarithmic size classes (Sheldon et al. 1972). Thus, even though small and large copepods feed on differently sized particles, the biomass of the food available to them is approximately the same in the average pelagic environment. It has been suggested that the ingestion rate of small copepods saturates at lower food concentrations than that of larger copepods (e.g. Lam \& Frost 1976). However, a recent extensive review has documented that the halfsaturation constant of the functional response in ingestion rate to food concentration is size independent in copepods (P. J. Hansen, B. Hansen \& P. K. Bjørnsen pers. comm.).

This analysis, thus, suggests that the mortality of planktonic copepods is invariable with adult size per se. More realistic and complex models, operating with age-/stage-dependent mortality rates, will not alter this conclusion materially. This conclusion is at variance with the pattern for aquatic organisms in general (Peterson \& Wroblewski 1984) and pelagic invertebrates in particular (McGurk 1986); mortality rates typically scale with body mass ${ }^{-0.25}$.

\section{Mortality rates of sac- and broadcast spawners}

Sac spawners develop at the same rate as broadcast spawners, but they have somewhat lower juvenile growth rates. This is basically a consequence of the eggs being relatively larger in sac spawners, and the weight increment from egg to adulthood consequently smaller. The similar developmental times and the very different egg production rates suggest that, overall, mortality rates are higher in broadcast than in sac spawners (cf. Eq. 5 and Fig. 8). Kiørboe \& Sabatini (1994) considered the different demography and life-cycle strategies of sac- and broadcast spawners in detail and suggested that this difference in mortality was mainly due to an order of magnitude higher mortality rate of free than of carried eggs.

Age-/stage-dependent variation in mortality

The conclusion above, that copepod mortality rates do not vary with body mass, does not necessarily imply that mortality is age- or stage-independent. In fact, the patterns in growth and developmental rates may suggest that the mortality is elevated in the nauplii as compared to that in the copepodid stages.

Nauplii develop much faster than copepodids (by a factor of 2 ; Table 2), but they grow slower (by 20 to $40 \%$; Table 3 ) both in sac- and in broadcast spawners. One possible and straightforward interpretation of this pattern is, that due to a lower swimming and escape capability, nauplii suffer a higher predation mortality risk than copepodids. It would, therefore, be adaptive to pass through the nauplii stages and develop motility/escape performance as quickly as possible in order to minimize cumulative pre-spawning mortality, 
and this may be at the cost of a reduced somatic growth rate. Unfortunately, field data on nauplii and copepodid mortality rates are far too scarce to examine this interpretation.

\section{Conclusions}

Cross-taxonomic patterns in development, growth and fecundity rates in planktonic copepods suggest that (1) mortality rates are independent of body mass per se, (2) that nauplii experience higher mortality rates than copepodids, and (3) that broadcast spawners suffer from higher overall mortality rates than eggcarrying copepods, particularly in the egg stage. While the differences between egg-carrying- and broadcastspawning copepods may relate to different life-cycle strategies (Kiørboe \& Sabatini 1994), and the difference between nauplii and copepodids may reflect differences in predator escape capability, the apparent size independency of copepod mortality is at variance with the general pattern in aquatic invertebrates and remains unexplained.

Acknowledgements. This work was supported by grants from the Danish Science Research Council (no. 11-0420-1) to T.K. and from the Argentinian Science Research Council (CONICET, JUB91/res. 8) and the Commission of European Communities $(B / 11 \cdot-913134)$ to $M . S$

\section{LITERATURE CITED FOR TEXT}

Banse, K. (1982). Mass-scaled rates of respiration and intrinsic growth in very small invertebrates. Mar. Ecol. Prog. Ser. 9: $281-297$

Bergreen, U., Hansen, B., Kiørboe, T (1988). Food size spectra, ingestion and growth of the copepod Acartia tonsa: implications for the determination of copepod production. Mar. Biol. 99: 341-352

Dagg, M. (1994). Marine snow in the Northern Gulf of Mexico. EOS, Trans. Am. Geophys. Un. 75: 36

Eaton, J. M. (1971). Studies on the feeding and reproductive biology of the marine cyclopoid copepod Oithona similis Claus. Ph.D. thesis, Dalhousie University, Halifax

Fenchel, $T$ (1974). Intrinsic rate of natural increase: the relationship with body size. Oecologia 14: $31.7-326$

Frost, B. W. (1980). The inadequacy of body size as an indicator of niches in the zooplankton. In Kerfort, W. C. (ed.) Evolution and ecology of zooplankton communities. Univ. Press of New England, Hanover, p. 742-753

Haq, S. M. (1965). The larval development of Oithonina nana. J. Zool. 146: 555-566

Hart, R. C. (1990). Copepod post-embryonic durations: pattern, conformity, and predictability. The realities of isochronal development, and trends in the copepodidnaupliar duration ratio. Hydrobiologia 206: 175-206

Hemmingsen, A. M. (1960). Energy metabolism as related to body size and respiratory surfaces, and its evolution. Rep. Steno Mem. Hosp. Nord. Insulin Lab. 8: 1-110
Hirche, H.-J., Bohrer, R. N. (1987). Reproduction of the Arctic copepod Calanus glacialis in Fram Strait. Mar. Biol. 94: $11-17$

Huntley, M. E., Lopez, M. D. G. (1992). Temperature dependent production of marine copepods: a global synthesis. Am. Nat. 140: 201-242

Ivleva, I. V. (1980). The dependence of crustacean respiration rate on body mass and habitat temperature. Int. Rev. ges. Hydrobiol. 65: 1-47

Katona, S. K. (1970). Growth characteristics of the copepods Eurytemora affinis and E. herdmani in laboratory cultures. Helgoländer wiss. Meeresunters. 20: 373-384

Kiørboe, T (1991). Pelagic fisheries and spatio-temporal variability in zooplankton productivity. Bull. Plankton Soc. Jap. Spec. vol.: 229-249

Kiørboe, T., Møhlenberg, F., Hamburger, K. (1985). Bioenergetics of the planktonic copepod Acartia tonsa: relation between feeding, egg production and respiration, and composition of specific dynamic action. Mar. Ecol. Prog. Ser. 25: 85-97

Kiorboe, T., Sabatini, M. (1994). Reproductive and life cycle strategies in egg-carrying cyclopoid and free-spawning calanoid copepods. J. Plankton Res. 16: 1353-1366

Landry, M. R. (1983). The development of marine calanoids with comment on the isochronal rule. Limnol. Oceanogr. 28: $614-624$

Lam, R. K., Frost, B. (1976). Model of copepod filtering response to changes in size and concentration of food. Limnol. Oceanogr. 21: 490-500

McGurk, M. D. (1986). Natural mortality of marine pelagic fish eggs and larvae: role of spatial patchiness. Mar. Ecol. Prog. Ser. 34: 227-242

Nielsen, S. L., Sand-Jensen, K. (1990). Allometric scaling of maximal photosynthetic growth rate to surface/volume ratio. Limnol. Oceanogr. 35: 177-181

Paffenhöfer, G.-A. (1993). On the ecology of marine cyclopoid copepods (Crustacea, Copepoda, Cyclopoida). J. Plankton Res. 15: 37-55

Paffenhöfer, G.-A., Harris, R. P. (1976). Feeding, growth and reproduction of the marine planktonic copepod Pseudocalanus elongatus Boeck. J. mar. biol. Ass. U.K. 56: $327-344$

Parsons, T. R., Takahasi, M., Hargrave, B. (1984). Biological oceanographic processes. Pergamon Press, New York

Peters, R. H., Downing, J. A. (1984). Empirical analysis of zooplankton filtering and feeding rates. Limnol. Oceanogr. 29: $763-784$

Peterson, I., Wroblewski, J. S. (1984). Mortality rates of fishes in pelagic ecosystems. Can. J. Fish. Aquat. Sci. 41 $1117-1120$

Peterson, W. T., Painting, S. (1990). Developmental rates of the copepods Calanus australis and Calanoides carinatus in the laboratory, with discussion of methods used for calculation of development time. J. Plankton Res. 12: 283-293

Sabatini, M., Kiørboe, T (1994). Egg production, growth and development of the cyclopoid copepod Oithona similis. J. Plankton Res. 16: 1329-1351.

Sheldon, R. W., Prakash, A., Sutcliffe, W. H. Jr (1972). The size distribution of particles in the ocean. Limnol. Oceanogr. 17: $327-340$

Vidal, J, Whitledge, T. E. (1982). Rates of metabolism of planktonic crustaceans as related to body weight and temperature of habitat. J. Plankton Res. 4: 77-84

Zeuthen, E. (1953). Oxygen uptake as related to body size in organisms. Q. Rev. Biol. 28: 1-12 
Appendix 1. Egg and female carbon wejght of several species of copepods. Averages of all the available data for each species are also given. - Egg-carbon was calculated from volume and references thereby refer to the egg-diametel

\begin{tabular}{|c|c|c|c|c|c|c|}
\hline Species & $\begin{array}{c}W_{\text {egg }} \\
(\mu g C)\end{array}$ & Source & $\begin{array}{c}W_{Q} \\
(\mu g C)\end{array}$ & Source & $\begin{array}{l}\text { Av. } W_{\text {egg }} \\
(\mu g C)\end{array}$ & $\begin{array}{l}\text { Av. } W_{\circ} \\
(\mu g C)\end{array}$ \\
\hline \multicolumn{7}{|l|}{ Sac spawners } \\
\hline \multirow[t]{2}{*}{ Pseudocalanus elongatus } & $0.140^{\circ}$ & Frost (1989) & 8.5 & Paffenhofer \& Hams (1976) & 0.140 & 8.4 \\
\hline & & & 8.3 & Klein Breteler et al (1982) & & \\
\hline Pseudocalanus sp. & & & 6.4 & Vidal (1980a) & & \\
\hline Pseudocalanus moultoni & $0.150^{\circ}$ & Frost (1989) & 5.1 & Sigrun Jonasdottir pers. comm. & 0.150 & 5.1 \\
\hline Pseudocalanus minutus & $0.170^{\circ}$ & Frost (1989) & 8.6 & Dagg (1977) & 0.170 & 8.6 \\
\hline Pseudodiaptomus hessel & & & 10.2 & Jerling \& Wooldridge (1991) & & \\
\hline Pseudodiaptomus mannus & 0.100 & Uye et al. (1983) & 6.5 & Uye et al. (1983) & 0.100 & 6.5 \\
\hline Euchaeta norvegica & 6.000 & Hopkins (1977) & 722.0 & Hopkins (1977) & 6.000 & 722.0 \\
\hline \multirow[t]{2}{*}{ Eurytemora affinss } & $0.043^{\cdot}$ & Hirche (1992) & 2.3 & Hirche (1992) & 0.048 & 2.30 \\
\hline & 0.052 & Heinle \& Flemer (1975) & & & & \\
\hline \multirow[t]{3}{*}{ Eurytemora herdmani } & 0.029 & McLaren \& Corkett (1981) & 1.4 & McLaren \& Corkett (1981) & 0.029 & 1.78 \\
\hline & & & 2.9 & Escribano \& McLaren (1992) & & \\
\hline & & & 1.0 & Escribano \& McLaren (1992) & & \\
\hline Oithona davisae & $0.009^{\circ}$ & Uchima (1979) & 0.2 & Hiromi et al. (1988) & 0.009 & 0.23 \\
\hline Oithona nana & & & 0.2 & Lampitt \& Gamble (1982) & & 0.20 \\
\hline Oithona plumifera & $0.038^{\circ}$ & Own unpubl obs. & 1.6 & G.-A. Paffenhöfer pers. comm. & 0.038 & 1.63 \\
\hline Oithona sumilis & $0.014^{*}$ & Sabatini \& Kuorboe (1994) & 0.6 & Sabatini \& Kuorboe (1994) & 0.014 & 0.60 \\
\hline Oncaea mediterranea & $0.014^{\bullet}$ & Böttger-Schnack et al. (1989) & 2.6 & G.-A. Paffenhofer pers. comm. & 0.014 & 2.60 \\
\hline \multicolumn{7}{|l|}{ Broadcast spawners } \\
\hline \multirow[t]{3}{*}{ Acartia clausi } & $0.030^{\circ}$ & Corkett \& McLaren (1970) & 2.5 & Landry (1978) & 0036 & 2.67 \\
\hline & & & 1.5 & Uye (1981) & & \\
\hline & & & 4.8 & Klein Breteler et al. (1982) & & \\
\hline Acartia clausi hudsonica & 0.041 & Sekiguch: et al. (1980) & 2.5 & Sekiguchi et al. (1980) & & \\
\hline Acartia claus $1=$ A. omori & & & 2.0 & Landry (1983) & & \\
\hline \multirow{5}{*}{$\begin{array}{l}\text { Acartia grani } \\
\text { Acartia tonsa }\end{array}$} & $0.030^{\circ}$ & Vilela (1972) & & & & \\
\hline & 0.046 & Kigrboe et al (1985a) & 3.3 & Kiorboe et al. (1985a) & 0.046 & 3.98 \\
\hline & & & 3.4 & Ambler (1986) & & \\
\hline & & & 4.0 & Landry (1983) & & \\
\hline & & & 5.2 & Dagg (1977) & & \\
\hline Calanoides carinatus & 0.320 & Borcher \& Hutchungs (1986) & & & & \\
\hline \multirow[t]{2}{*}{ Calanus australis } & 0.240 & Attwood \& Peterson $(1989)$ & 73.6 & Attwood \& Peterson (1989) & 0.240 & 80.80 \\
\hline & & & 88.0 & Peterson \& Painting (1990) & & \\
\hline \multirow[t]{2}{*}{ Calanus finmarchicus } & 0.400 & Hirche (1990) & 101.0 & Hirche (1990) & 0.400 & 119.5 \\
\hline & & & 137.3 & Smith $(1990)$ & & \\
\hline Calanus glacialis & 0.440 & Hirche (1989) & 307.3 & Hirche (1989) & 0.440 & 258.00 \\
\hline & & & 209.0 & Smith (1990) & & \\
\hline Calanus helgolandicus & $0.320^{\circ}$ & McLaren (1965) & 711 & Paffenhofer (1976) & 0.320 & 71.10 \\
\hline Calanus hyperboreus & 0.560 & Conover (1967) & 757.0 & Smith (1990) & & \\
\hline Calanus marshallae & 0.188 & Vidal \& Smith (1986) & 239.6 & Vidal \& Smith (1986) & 0.188 & 171.80 \\
\hline & & & 104.0 & Peterson (1988) & & \\
\hline Calanus pacificus & 0.250 & Frost $(1980)$ & 80.4 & Runge (1984) & 0.250 & 80.40 \\
\hline & & & 117.0 & Vidal (1980a) & & \\
\hline Calanus propingus & 0.370 & Kosobokova (1992) & 215.0 & After Huntley \& Lopez (1992) & 0.370 & 215.00 \\
\hline Calanus sinicus & 0.200 & Uye (1988) & 80.0 & Uye (1988) & 0.200 & 80.00 \\
\hline Centropages typicus & $0.031^{\bullet}$ & $\operatorname{Dagg}(1977)$ & 14.9 & Dagg (1977) & 0.032 & 14.28 \\
\hline & $0.027^{\bullet}$ & Davis \& Alatalo (1992) & 10.5 & Davis \& Alatalo (1992) & & \\
\hline & 0.037 & Fryd et al. (1991) & 14.4 & M. Fryd pers comm. & & \\
\hline & & & 17.3 & Smith \& Lane (1985) & & \\
\hline Centropages hamatus & $0.040^{\circ}$ & Klein Breteler (1982) & 10.0 & Klein Breteler et al. (1982) & 0.040 & 10.00 \\
\hline Eucalanus bungii & 0.204 & Vidal \& Smith (1986) & 258.0 & Vidal \& Smith (1986) & 0.204 & 258.00 \\
\hline Labidocera trispinosa & 0.050 & After Huntley \& Lopez (1992) & 33.0 & Landry (1983) & 0.050 & 33.00 \\
\hline Labidocera euchaeta & $0.160^{\circ}$ & Shaojing et al. (1989) & 48.0 & Senjle \& Song (1990b) & 0.160 & 48.00 \\
\hline Metridla pacifica & 0.100 & Vidal \& Smith (1986) & 51.6 & Vidal \& Smith (1986) & 0.100 & 51.60 \\
\hline Paracalanus parvus & 0.022 & Checkley (1980) & 3.0 & Checkley (1980), Landry (1983) & 0.022 & 3.00 \\
\hline Paracalanus sp. & & & 3.5 & Uye \& Shibuno (1992) & & \\
\hline Temora longicornis & 0.040 & Frost $(1980)$ & 18.4 & Harrıs \& Paffenhöfer (1976) & 0.040 & 14.95 \\
\hline & & & 11.5 & Klein Breteler et al. (1982) & & \\
\hline Temora stylifera & 0.059 & Abou Debs \& Nival (1983) & 12.6 & Abou Debs \& Nival (1983) & 0.059 & 12.60 \\
\hline Tortanus discaudatus & $0.082^{\circ}$ & McLaren (1966) & 20.0 & Lawrence \& Sastry (1985) & 0.082 & 20.00 \\
\hline Sinocalanus tenellus & 0.036 & Kimoto et al. (1986b) & 5.1 & Kimoto et al. (1986a) & 0.036 & 5.10 \\
\hline Undinula vulgaris & 0.220 & Park \& Landry (1993) & 67.7 & Park \& Landry (1993) & 0.220 & 67.70 \\
\hline
\end{tabular}


Appendix 2. Maximum egg production rates and weight-specific fecundities converted to $15^{\circ} \mathrm{C}$ by assuming a $\mathrm{Q}_{10}=3.0$. Female carbon contents also shown

\begin{tabular}{|c|c|c|c|c|}
\hline Species & $\begin{array}{c}\text { Egg production } \\
\text { rate } 15^{\circ} \mathrm{C} \\
\text { (no. of eggs }{ }^{-1} \mathrm{~d}^{-1} \text { ) }\end{array}$ & $\begin{array}{l}\text { Weight-specific } \\
\text { fecundity } 15^{\circ} \mathrm{C} \\
\qquad\left(d^{-1}\right)\end{array}$ & Source & $\begin{array}{c}W_{Q} \\
(\mu \mathrm{g} C)\end{array}$ \\
\hline \multicolumn{5}{|l|}{ Sac spawners } \\
\hline Euchaeta norvegica & 2.77 & 0.023 & Hopkins (1977) & 722.0 \\
\hline Euterpina acutifrons & 9.35 & 0.230 & Zurlıni et al. (1978) & 0.9 \\
\hline Oithona similis & 4.50 & 0.100 & Sabatini \& Kiorboe (1994) & 0.6 \\
\hline Pseudocalanus elongatus & 4.75 & 0.078 & Corkett \& Zillioux (1975) & 8.4 \\
\hline Pseudocalanus elongatus & 5.53 & 0.090 & Paffenhöfer \& Harris (1976) & 8.5 \\
\hline Pseudocalanus elongatus & 2.70 & 0.110 & Frost $(1985)$ & 8.4 \\
\hline Pseudocalanus minutus & 4.00 & 0.100 & Dagg (1977) & 8.6 \\
\hline Pseudocalanus moultonı & 7.51 & 0.080 & Jonasdottir (1989) & 5.1 \\
\hline Pseudocalanus newmani & 5.56 & 0.060 & Jonasdottir (1989) & 4.7 \\
\hline Pseudodiaptomus marinus & 6.48 & 0.100 & Uye et al. (1983) & 6.5 \\
\hline \multicolumn{5}{|l|}{ Broadcast spawners } \\
\hline Acartia californiensis & 19.91 & 0.149 & Trujillo Ortiz (1990) & 4.0 \\
\hline Acartia clausl & 40.41 & 0.346 & Landry (1978) & 2.5 \\
\hline Acartia clausi & 10.60 & 0.140 & Iwasaki et al. (1977) & 2.7 \\
\hline Acartia clausi & 23.09 & 0.375 & Uye (1981) & 1.5 \\
\hline Acartia clausi $=$ A. omor $i$ & 38.91 & 0.486 & Ayukai (1988) & 2.7 \\
\hline Acastia steveri & 25.40 & 0.294 & Uye (1981) & 3.9 \\
\hline Acartia tonsa & 50.00 & 0.290 & Dagg (1977) & 5.2 \\
\hline Acartia tonsa & 22.00 & 0.280 & Ambler (1986) & 3.4 \\
\hline Acartia tonsa & 25.58 & 0.192 & Corkett \& Zillioux (1975) & 4.0 \\
\hline Acartia tonsa & 33.52 & 0.467 & Kiørboe et al. (1985b) & 4.0 \\
\hline Acartia clausi hudsonica & 20.00 & 0.320 & Sekiguchi et al. (1980) & 2.5 \\
\hline Calanoides carianatus & 50.35 & 0.340 & Borchers \& Hutchings (1986) & 48.0 \\
\hline Calanus australis & 40.00 & 0.130 & Attwood \& Peterson (1989) & 73.6 \\
\hline Calanus marshallae & 41.57 & 0.120 & Peterson (1988) & 104.0 \\
\hline Calanus pacificus & 28.00 & 0.090 & Razouls et al. (1991) & 98.7 \\
\hline Calanus pacificus & 75.08 & 0.233 & Runge (1984) & 80.4 \\
\hline Centropages hamatus & 17.00 & 0.083 & Tiselıus et al. (1987) & 10.0 \\
\hline Centropages hamatus & 40.00 & 0.160 & Fryd et al. (1991) & 10.0 \\
\hline Centropages typicus & 60.00 & 0.149 & $\operatorname{Dagg}(1977)$ & 14.9 \\
\hline Centropages typicus & 103.55 & 0.272 & Fryd et al. (1991) & 14.4 \\
\hline Centropages typicus & 94.92 & 0.203 & Smith \& Lane (1985) & 17.3 \\
\hline Centropages typucus & 60.00 & 0.160 & Nival et al. (1990)، Davis \& Alatalo (1992) & 10.5 \\
\hline Centropages typicus & 65.00 & 0.159 & Tiselius et al. (1987) & 14.3 \\
\hline Labidocera euchaeta & 45.00 & 0.150 & Seinje \& Song (1989) & 48.0 \\
\hline Paracalanus parvus & 37.40 & 0.274 & Checkley $(1980)$ & 3.0 \\
\hline Paracalanus parvus & 22.00 & 0.264 & Tiselius et al. (1987) & 3.0 \\
\hline Paracalanus sp. & 29.40 & 0.210 & Uye \& Shibuno (1992) & 3.5 \\
\hline Sinocalanus tenellus & 34.64 & 0.214 & Kimoto et al. (1986b) & 5.1 \\
\hline Temora longicornis & 16.56 & 0.044 & Corkett \& Zillioux (1.975) & 15.0 \\
\hline Temora longicornis & 24.00 & 0.133 & Tiselius et al. (1987) & 15.0 \\
\hline Temora longicornis & 31.85 & 0.069 & Harris \& Paffenhofer $(1976)$ & 18.4 \\
\hline Temora stylefera & 35.84 & 0.170 & Abou Debs \& Nival (1983) & 12.6 \\
\hline Tortanus discaudatus & 36.12 & 0.181 & Lawrence \& Sastry (1985) & 20.0 \\
\hline Undinula vulgaris & 11.84 & 0.039 & Park \& Landry (1993) & 67.7 \\
\hline
\end{tabular}


Appendix 3. Development times converted to $15^{\circ} \mathrm{C}$ by assuming a $Q_{10}=3.0$. The somewhat variable definitions of developmental times among studies have been indicated. Carbon content of females also shown

\begin{tabular}{|c|c|c|c|c|}
\hline Species & $\begin{array}{l}\text { Dev. tume } \\
15^{\circ} \mathrm{C} \text {, d }\end{array}$ & Defined as & Source & $\begin{array}{l}W_{9} \\
(\mu g C)\end{array}$ \\
\hline \multicolumn{5}{|l|}{ Sac spawners } \\
\hline Eurytemora affinss & 18.10 & Hatching to adult & Heinle \& Flemer $\{1975\}$ & 2.3 \\
\hline Eurytemora affinis & 23.55 & Egg to ovigerous fem. & Katona $(1970)$ & 2.3 \\
\hline Eurytemora herdman! & 19.00 & Egg to ovigerous fem & Katona $(1970)$ & 1.8 \\
\hline Othona colcarva & 26.00 & Hatching to adult & Lonsdale (1981) & 0.45 \\
\hline Oithona dawsae & 37.26 & Hatching to adult & Uchima (1979) & 0.23 \\
\hline Oithona nana & 33.45 & Hatching to egg-layıng & $\mathrm{Haq}(1965\}$ & 0.2 \\
\hline Oithona similis & 19.70 & Egg to adult & Sabatini \& Kiorboe (1994) & 0.6 \\
\hline Pseudocalanus elongatus & 21.00 & Egg to adult & Landry (1983) & 8.4 \\
\hline Pseudocalanus elongatus & 21.36 & Hatching to adult & Thompson (1982) & 8.4 \\
\hline Pseudocalanus elongatus & 19.07 & Hatching to adult & Paffenhöfer \& Harris (1976) & 8.4 \\
\hline Pseudodiapto hessei & 31.24 & Egg to adult & Jerlings \& Wooldridge (1991) & 10.24 \\
\hline Pseudodiaptomus marinus & 38.73 & Egg to adult & Uye et al. (1983) & 6.5 \\
\hline Oncaea mediterranea & 51.06 & Hatching to adult & Paffenhöfer (1993) & 2.6 \\
\hline \multicolumn{5}{|l|}{ Broadcast spawners } \\
\hline Acartia tonsa & 20.30 & Egg to adult & Landry $(1983)$ & 4 \\
\hline Calanoides carinatus & 19.37 & Egg to adult & Peterson \& Painting $(1990)$ & 48 \\
\hline Calanoides carinatus & 21.00 & Egg to adult & Hirche $(1980)$ & 48 \\
\hline Calanoides carinatus & 16.85 & Egg to adult & Borchers \& Hutchıngs (1986) & 48 \\
\hline Calanus helgolandicus & 26.20 & Hatching to adult & Thompson (1982) & 71.1 \\
\hline Calanus australis & 21.48 & Egg to adult & Peterson \& Painting (1990) & 88 \\
\hline Calanus marshallae & $\begin{array}{l}21.40 \\
36.00\end{array}$ & Egg to adult & Peterson (1986) & 104 \\
\hline Calanus pacificus & 19.80 & Egg to adult. & Landry (1983) & 98.7 \\
\hline Calanus pacificus & 23.00 & Egg to adult & Mullin \& Brooks (1970) & 98.7 \\
\hline Calanus sinicus & 24.70 & Eqg to adult & Uve (1988) & 80 \\
\hline Centropages hamatus & 27.36 & Egg to adult & Fryd et al. (1991) & 10 \\
\hline Centropages typicus & 20.31 & Egg to adult & Fryd et al (1991) & 14.4 \\
\hline Centropages typicus & 25.82 & Egg to adult & Carlotti \& Nival (1992) & $\begin{array}{l}14.4 \\
14.3\end{array}$ \\
\hline Centropages typicus & 27.83 & Egg to adult. & Smith \& Lane (1985) & 17.32 \\
\hline Labidocera euchaeta & 46.39 & Egg to adult & Senjie \& Song (1990d) & 48 \\
\hline Paracalanus parvus & 18.60 & Egg to adult & Landry (1983) & 3 \\
\hline Paracalanus parvus & 1.7 .80 & Hatching to adult & Davis (1984) & 3 \\
\hline Sinocalanus tenellus & 21.20 & Egg to adult. & Kimoto et al. (1986a) & 5.12 \\
\hline Temora longicornis & 18.61 & Hatching to adult & Harris \& Paffenhöer (1976) & 18.4 \\
\hline
\end{tabular}

Appendix 4. Developmental rates of nauplit, copepodids and late copepodids $(\mathrm{C} 4$ or $\mathrm{C} 5$ to $\mathrm{C} 6)$ converted to $15^{\circ} \mathrm{C}$ by assuming a $\mathrm{Q}_{10}=3.0$. Developmental rates were calculated as the inverse of the stage duration; stage durations were calculated either from median development time (50\% fractle of cohort) (MDT), mean time of stages (MTS), or from mean duration for isolated individuais (MDII). Species with both C4 and CS of longer duration than younger stages

\begin{tabular}{|c|c|c|c|c|c|c|}
\hline Species & \multicolumn{3}{|c|}{ Developmental rate $15^{\circ} \mathrm{C}$ (stage $\mathrm{h}^{-1}$ ) } & Method & Source & $\begin{array}{c}W_{\circ} \\
(\mu g \subset)\end{array}$ \\
\hline \multicolumn{7}{|l|}{ Sac spawners } \\
\hline Eurytemora herdmani & & 0.032 & 0.025 & MTS & Escribano \& McLaren (1992) & 1.8 \\
\hline Oithona davisae & 0.018 & 0.014 & 0.008 & MTS & Lchima (1979) & 0.2 \\
\hline Outhona similis & 0.025 & 0.025 & & $\mathrm{MDT}^{\top}$ & Sabatini \& Kiorboe $(1994\}$ & 0.6 \\
\hline Pseudocalanus elongatus & 0.099 & 0.017 & 0.016 & MDII & Thompson (1982) & 8.4 \\
\hline Pseudocalanus sp. & 0.037 & 0.020 & 0.017 & MDT & Landry (1983) & 8.4 \\
\hline Pseudodiaptomus hessei & 0.018 & 0.015 & 0.011 & MDll & Jerling \& Wooldndge (1991) & 10.2 \\
\hline Pseudodiaplomus marinus & 0.021 & 0.008 & 0.008 & MTS & Uye \& Onbé $(1975)$ & 6.5 \\
\hline \multicolumn{7}{|l|}{ Broadcast spawners } \\
\hline Acartia tonsa & 0.032 & 0.032 & & MDT & Berggreen et al. (1988) & 4.8 \\
\hline Acartia tonsa & 0.030 & 0.023 & 0.017 & MDT & Landry (1983) & 4.0 \\
\hline Acartua clausı & & 0.023 & & MDT & Landry (1983) & 2.0 \\
\hline Calanoides cannatus & 0.039 & 0.021 & 0.013 & MDT & Peterson \& Painting (1990) & 48.0 \\
\hline Calanus australis & 0.033 & 0.020 & 0.013 & MDT & Peterson \& Paintıng (1990) & 88.0 \\
\hline Calanus pacificus " & 0.043 & 0.021 & 0.012 & MDT & Landry (1983) & 1170 \\
\hline Calanus pacificus ${ }^{*}$ & & 0.014 & 0.009 & MDT & Vidal (1980b) & 117.0 \\
\hline Calanus marshallae & 0.016 & 0.016 & 0.009 & MDT & Peterson (1986) & 106.0 \\
\hline Calanus helgolandicus " & 0.047 & 0.012 & 0.009 & MTS & Thompson (1982) & 71.1 \\
\hline Calanus sinicus & 0.035 & 0.018 & 0.008 & MDT & Uye $(1988\}$ & 80.0 \\
\hline Sinocalanus tenellus & 0.042 & 0.024 & 0.012 & MDT & Kimoto et al. (1986a) & 5.1 \\
\hline Rnincalanus nasutus " & 0.033 & 0.016 & 0.014 & MDT & Landry (1983) & 150.0 \\
\hline Centropages hamatus & 0.021 & 0.015 & 0.014 & MDT & Fryd et al. (1991) & 10.0 \\
\hline Centropages typicus ${ }^{\circ}$ & 0.032 & 0.019 & 0.014 & MDT & Fryd et al. $\{199 \pi\}$ & 14.3 \\
\hline Centropages typicus & & 0.015 & 0.012 & MDII & Carlotti \& Nival (1992) & 14.3 \\
\hline Centropages typicus ${ }^{\circ}$ & & 0.029 & 0.009 & MDT & Smith \& Lane (1985) & 14.3 \\
\hline Labidocera trispinosa & 0.028 & & & MDT & Landry (1983) & 33.0 \\
\hline Labidocera euchaeta & 0.113 & 0.006 & 0.004 & MTS & Senjie \& Song (1990a) & 48.0 \\
\hline Paracalanus parvus & 0.042 & 0.019 & 0.015 & MDT & Landry (1983) & 3.0 \\
\hline Temora longicomis " & 0.029 & 0.020 & 0.011 & MDT & Klein Breteler \& Gonzalez (1986) & 8.4 \\
\hline
\end{tabular}


Appendix 5. Weight-specific growth rates of nauplii, copepodids and/or for the entre development, converted to $15^{\circ} \mathrm{C}$ by assumung a $Q_{t 0}=3.0$, Female carbon contents also shown

\begin{tabular}{|c|c|c|c|c|c|c|}
\hline \multirow[t]{2}{*}{ Species } & \multirow[b]{2}{*}{ Nauplii } & \multicolumn{3}{|c|}{ Growth rate $15^{\circ} \mathrm{C}\left(\mathrm{d}^{-1}\right)$} & \multirow[t]{2}{*}{ Source } & \multirow{2}{*}{$\begin{array}{c}W_{8} \\
(\mu g \mathrm{C})\end{array}$} \\
\hline & & Copepodids & All & $\mathrm{C} 4$ or $\mathrm{C} 5$ to $\mathrm{C} 6$ & & \\
\hline \multicolumn{7}{|l|}{ Sac spawners } \\
\hline Eurytemora herdmani & & 0.354 & & & Escribano \& McLaren (1992) & 2.9 \\
\hline Eurytemora affinis & & & 0.250 & & Heinle \& Flemer (1975) & 2.3 \\
\hline Pseudodiaptomus marinus & 0.133 & 0.205 & & 0.197 & Uye et al. \{1983\} & 6.5 \\
\hline Pseudocalanus sp. & & 0.220 & & 0.166 & Vidal $(1980 \mathrm{~b})$ & 7.2 \\
\hline Pseudocalanus elongatus & 0.198 & 0.230 & & 0.210 & Klein Breteler et al. (1982) & 8.3 \\
\hline Pseudocalanus elongatus & 0.211 & 0.324 & & 0.232 & Paffenhöfer \& Harris $\{1976$ ) & 8.5 \\
\hline Oithona simils & & & 0.200 & 0.074 & Sabatini \& Kiørboe (1994) & 0.6 \\
\hline Oncaea mediterranea & & 0.150 & & Decreases & Paffenhöfer \{1993\} & 2.6 \\
\hline \multicolumn{7}{|l|}{ Broadcast spawners } \\
\hline Acartia clausi & 0.378 & 0.336 & & 0.330 & Klein Breteler et al. (1982) & 4.8 \\
\hline Acartia clausi (A. omori) & 0.294 & 0.358 & & & Uye (1988) & 2.7 \\
\hline Acartia tonsa & & & 0.361 & & Berggreen et al. (1988) & 4.5 \\
\hline Calanus helgolandicus & 0.410 & 0.410 & & 0.195 & Paffenhöfer (1976) & 71.1 \\
\hline Calanus marshallae & & & 0.305 & & Peterson (1986) & 104.0 \\
\hline Calanus pacificus & & 0.329 & & 0.141 & Vidal (1980b) & 117.0 \\
\hline Calanus sinicus & 0.341 & 0.462 & & 0.127 & Uye (1988) & 80.0 \\
\hline Centropages hamatus & 0.170 & 0.186 & 0.172 & & Fryd et al. (1991) & 10.0 \\
\hline Centropages hamatus & 0.275 & 0.356 & & 0.350 & Klein Breteler et al. (1982) & 10.0 \\
\hline Centropages typicus & 0.282 & 0.302 & 0.279 & & Fryd et al. (1991) & 15.0 \\
\hline Labidocera euchaeta & & 0.176 & & 0.114 & Senjie \& Song (1990b) & 48.0 \\
\hline Paracalanus parvus & 0.173 & 0.271 & & & Uye (1988) & 3.0 \\
\hline Paracalanus sp. & 0.180 & 0.390 & & & Uye (1991), Uye \& Shibuno (1992) & 3.5 \\
\hline Sinocalanus tenellus & 0.296 & 0.413 & & 0.296 & Kimoto et al. (1986a) & 5.1 \\
\hline Temora longicornis & 0.237 & 0.408 & & 0.329 & Harris \& Paffenhoter (1976) & 18.4 \\
\hline Temora longicornis & 0.250 & 0.356 & & 0.350 & Klein Breteler et al. (1982) & 11.5 \\
\hline
\end{tabular}

Appendix 6. Growth rates $(g)$ estimated from egg and female carbon contents ( $W_{\text {egq }}$ and $W_{p}$, respectively) and development times $(D)$ converted to $15^{\circ} \mathrm{C}$, as $g=\ln \left(W_{Q} / W_{\text {egg }}\right) / D$

\begin{tabular}{|c|c|c|c|c|c|}
\hline Species & $\begin{array}{c}W_{Q} \\
(\mu \mathrm{g} C)\end{array}$ & $\begin{array}{c}W_{\text {egg }} \\
(\mu \mathrm{g} C)\end{array}$ & $\begin{array}{l}\text { Dev. time } \\
15^{\circ} \mathrm{C} \text { (d) }\end{array}$ & Source & $\begin{array}{c}\text { Growth rate } \\
\qquad\left(\mathrm{d}^{-1}\right)\end{array}$ \\
\hline \multicolumn{6}{|l|}{ Sac spawners } \\
\hline Eurytemora affinis & 2.3 & 0.043 & 18.10 & Heinle \& Flemer (1975) & 0.250 \\
\hline Eurytemora herdmani & 1.8 & 0.029 & 19.00 & Katona $(1970)$ & 0.217 \\
\hline Oithona davisae & 0.2 & 0.009 & 37.26 & Uchima (1979) & 0.087 \\
\hline Oithona similis & 0.6 & 0.014 & 19.70 & Sabatini \& Kiørboe (1994) & 0.191 \\
\hline Pseudocalanus elongatus & 8.3 & 0.143 & 21.00 & Landry (1.983), Thompson (1982) & 0.193 \\
\hline Pseudodiaptomus marinus & 6.5 & 0.047 & 38.50 & Uye et al. (1983) & 0.128 \\
\hline \multicolumn{6}{|l|}{ Broadcast spawners } \\
\hline Acartia clausi & 4.8 & 0.025 & 18.00 & Klein Breteler et al. (1982) & 0.292 \\
\hline Acartia tonsa & 4.8 & 0.030 & 20.30 & Landry (1983) & 0.250 \\
\hline Calanoides carinatus & 44.0 & 0.300 & 19.37 & Peterson \& Painting (1990) & 0.262 \\
\hline Calanus australis & 880 & 0.240 & 21.48 & Peterson \& Paintung (1990) & 0.273 \\
\hline Calanus marshallae & 104.0 & 0.188 & 36.00 & Peterson (1986) & 0.175 \\
\hline Calanus pacificus & 117.0 & 0.250 & 19.80 & Landry (1983) & 0.311 \\
\hline Calanus sinicus & 80.0 & 0.200 & 23.00 & Uye (1988) & 0.260 \\
\hline Calanus sp. ${ }^{\circ}$ & 71.1 & 0.320 & 26.20 & Thompson (1982) & 0.206 \\
\hline Centropages hamatus & 10.0 & 0.040 & 21.82 & Fryd et al. (1991) & 0.253 \\
\hline Centropages typicus & 14.3 & 0.037 & 20.31 & Fryd et al (1991) & 0.293 \\
\hline Labidocera euchaeta & 48.0 & 0.160 & 46.39 & Senjie \& Song (1990a) & 0.325 \\
\hline Paracalanus parvus & 3.0 & 0.030 & 17.80 & Landry (1983) & 0.259 \\
\hline Sinocalanus tenellus & 5.1 & 0.036 & 21.20 & Kimoto et al. (1986b) & 0.234 \\
\hline Temora longicornis & 18.4 & 0.040 & 32.50 & Harris \& Paffenhoter (1976) & 0.189 \\
\hline
\end{tabular}




\section{LITERATURE CITED FOR APPENDICES}

Abou Debs, Ch., Nival, P. (1983). Etude de la ponte et du developpment embryonnaire en relation avec la temperature et la nourriture chez Temora stylifera Dana (Copepoda, Calanoida). J. exp. mar. Biol. Ecol. 72: 125-145

Ambler, J. W. (1986). Effect of food quantity and quality on egg production of Acartia tonsa Dana from East Lagoon, Texas. Estuar. coast. Shelf Sci. 23: 183-196

Attwood, C. C., Peterson, W. T. (1989). Reduction in fecundity and lipids of the copepod Calanus australis (Brodskii) by strongly pulsed upwelling. J. exp. mar. Biol. Ecol. 129: 121-131

Ayukai, T (1988). Egg production by the planktonic calanoid copepod Acartia omorii in Onagawa harbor during springsummer. Bull. Plankton Soc. Jap. 35: 127-132

Berggreen, U., Hansen, B., Kiorboe, T (1988), Food size spectra, ingestion and growth of the copepod Acartia tonsa: implications for the determination of copepod production. Mar. Biol. 99: $341-352$

Borchers, P., Hutchings, L. (1986). Starvation tolerance, development time and egg production of Calanoides carinatus in the Southern Benguela Current. J. Plankton Res. 8: 855-874

Böttger-Schnack, R., Schnack, D., Weikert, H. (1989). Biological observations on small cyclopoid copepods in the Red Sea. J. Plankton Res. 11. 1089-1101

Carlotti, F., Nival, S. (1992). Moultung and mortality rates of copepods related to age within stage: experimental results. Mar. Ecol. Prog. Ser. 84: 235-243

Checkley, D. M. (1980). The egg production of a marine planktonic copepod in relation to its food concentration supply: laboratory studies. Limnol. Oceanogr. 25: 430-446

Conover, R. J. (1967). Reproductive cycle, early development, and fecundity in laboratory populations of the copepod Calanus hyperboreus. Crustaceana 13: 61-72

Corkett, C. J., McLaren, I. A. (1970). Relationships between development rate of eggs and older stages of copepods. J. mar. biol. Ass. U.K. 50: $161-168$

Corkett, C. J., Zillioux, E. J. (1975). Studies on the effect of temperature on the egg laying of three species of calanoid copepods in the laboratory (Acartia tonsa, Temora longicornis and Pseudsocalanus elongatus). Bull. Plankton Soc. Jap. 21:79-85

Dagg, M. (1977). Some effects of patchy food environments on copepods. Limnol. Oceanogr. 22: 99-107

Davis, C. S. (1984). Food concentration on Georges Bank: nonlimiting effect on development and survival of laboratory reared Pseudocalanus sp. and Paracalanus parvus (Copepoda: Calanoida). Mar. Biol. 82: 41-46

Davis, C. S., Alatalo, P. (1992). Effects of constant and intermittent food supply on life-history parameters in a marine copepod. Limnol. Oceanogr. 37: 1618-1639

Escribano, R., McLaren, I. A. (1992). Testing hypothesis of exponential growth and size-dependent molting rate in two copepod species. Mar. Biol. 114: 31-39

Frost, B. W. (1980). The inadequacy of body size as an indicator of niches in the zooplankton. In: Kerfort, W. C. (ed.) Evolution and ecology of zooplankton communities. Univ. Press of New England, Hanover, p. 742-753

Frost, B. W. (1985). Food limitation of the planktonic marine copepods Calanus pacificus and Pseudocalanus $\mathrm{sp}$. in a temperate fjord. Arch. Hydrobiol. Beih. Ergebn. Limnol. 21: 1-13

Frost, B. W. (1989). A taxonomy of the marine calanoid copepod genus Pseudocalanus. Can. J. Zool. 67: 525-551

Fryd, M., Haslund, O. H., Wohlgemuth, O. (1991). Development, growth and egg production of the two copepod species Centropages hamatus and Centropages typicus in the laboratory. J. Plankton Res. 13: 683-689

Haq, S. M. (1965). The larval development of Oithonina nana. J. Zool. 146: 555-566

Harris, R. P., Paffenhofer, G.-A. (1976). Feeding, growth and reproduction of the marine planktonic copepod Temora longicornis Müller. J mar. biol. Ass. U.K. 56: 675-690
Heinle, D. R. Flemer, D. A. (1975). Carbon requirements of a population of the estuanne copepod Eurytemora affinis. Mar. Biol. 31: $235-247$

Hirche, H.-J. (1980). The cultivation of Calanoides cannatus Kroyer (Copepoda: Calanoida) under different temperature and food conditions - with a description of the eggs and naupli. J. mar. biol. Ass. U.K. 60: 115-125

Hirche, H.J. (1989). Egg production of the Arctic copepod Calanus glacialis: laboratory experiments. Mar. Biol. 103: $311-318$

Hirche, H.-J. (1990). Egg production of Calanus finmarchicus at low temperature. Mar. Biol. 106: 53-58

Hirche, H.-J. (1992). Egg production of Eurytemora affinis effect of $k$-strategy. Estuar. coast. Shelf Sci. 35: 395-407

Hiromi, J., Nagata, T., Kadota, S. (1988). Respiration of the small planktonic copepod Oithona davisae at different temperatures. Bull. Plankton Soc. Jap. 35: 143-148

Hopkins, C. C. E. (1977). The relationship between maternal body size and clutch size, development time and egg mortality in Euchaeta norvegica (Copepoda: Calanoida) from Loch Etive, Scotland. J. Mar. biol. Ass. U.K. 57: 723-733

Huntley, M. E., Lopez, M. D. G. (1992). Temperature dependent production of marine copepods: a global synthesis. Am. Nat. 140: $201-242$

Iwasaki, H., Katoh, H. Fujiyama, . (1977). Cultivation of marine copepods, Acartia clausi Giesbrecht. I. Factors affecting the generation time and egg production. Bull. Plankton Soc. Jap. 24: $55-61$

Jerling, H. L., Wooldridge, T. H. (1991). Population dynamics and estimates of production for the calanoid copepod Pseudiaptomis hessei in a warm temperate estuary. Estuar. coast. Shelf Sci. 33: $121-135$

Jonasdottir, S. H. (1989). Effects of food concentration on eggproduction rates of two species of Pseudocalanus: laboratory observations. J. exp. mar. Biol. Ecol. 130: 33-43

Katona, S. K (1970). Growth characteristics of the copepods Eurytemora affinis and $E$. herdmani in laboratory cultures. Helgoländer wiss. Meeresunters. 20: 373-384

Kumoto, K., Uye, S.-1., Ombe, T. (1986a). Growth characteristics of a brackish-water calanoid copepod Sinocalanus tenellus in relation to temperature and salinity. Bull. Plankton Soc. Jap. 33: $43-57$

Kimoto, K., Uye, S.-I., Ombe, T. (1986b). Egg production of a a brackish-water calanoid copepod Sinocalanus tenellus in relation to food abundance and temperature. Bull. Plankton Soc. Jap. 33: 133-145

Kiørboe, T., Møhlenberg, F., Hamburger, K. (1985a). Bioenergetjcs of the planktonic copepod Acartia tonsa: relation between feeding, egg production and respiration, and composition of specific dynamic action. Mar. Ecol. Prog. Ser. 25: $85-97$

Kiørboe, T., Møhlenberg, F., Riisgård, H. U. (1985b). In situ feeding rates of planktonic copepods: a comparison of four methods. J. exp. mar. Biol. Ecol. 88: 67-81

Klein Breteler, W. C. M. (1982). The life stages of four pelagic copepods (Copepoda: Calanoida) illustrated by a series of photographs. Neth. Inst. Sea Res. Publ. Ser. 6: 1-32

Klein Breteler, W. C. M., Franz, H. G., Gonzalez, S. R. (1982). Growth and development of four calanoid copepod species under experimental and natural conditions. Neth. J. Sea Res. 16: $195-207$

Klein Breteler, W. C. M., Gonzalez, S. R. (1986). Culture and development of Temora longicornis (Copepoda, Calanoida) at different conditions of temperature and food. Syllogeus 58 : $71-84$

Kosobokova, K. N. (1992). An experimental study of the fecundity of the Antarctic copepod Calanus propinquus. Okeanologiya (Oceanology) 32: 134-140

Lampitt, R. S., Gamble, J. C. (1982). Diet and respiration of the small planktonic marine copepod Oithona nana. Mar. Biol. 66: $185-190$ 
Landry, M. R. (1978). Population dynamics and production of a planktonic marine copepod, Acartia clausii, in a small temperate lagoon on San Juan Island, Washington. Int. Rev. Ges. Hydrobiol. 63: $77-119$

Landry, M. R. (1983). The development of marine calanoids with comment on the isochronal rule. Limnol. Oceanogr. 28: $614-624$

Lawrence, S. A., Sastry, A. N. (1985). The role of temperature in seasonal variation in egg production by the copepod Tortanus discaudatus (Thompson and Scott) in Narragansett Bay. J. exp. mar. Biol. Ecol. 91. 151-167

Lonsdale, D. J. (1981). Influence of age-specific mortality on the life history of two estuarine copepods Mar. Ecol. Prog. Ser. 5: $333-340$

McLaren, I. A. (1965). Some relationships between temperature and egg size, body size, development rate, and fecundity of the copepod Pseudocalanus. Limnol. Oceanogr. 10: 528-538

McLaren, I. A. (1966). Predicting the development rate of copepod eggs. Biol. Bull. 131: 457-469

McLaren, I. A., Corkett, C. J. (1981). Temperature-dependent growth and production by a marine copepod. Can. J. Fish. Aquat. Sci. 38: 77-83

Mullin, M., Brooks, E. R. (1970). Growth and metabolism of two planktonic, marine copepods as influenced by temperature and the type of food. In: Steele, J. H. (ed.) Marine food chains. Oliver \& Boyd, Edinburgh, p. 74-95

Nival, S., Pagano, M., Nival, P. (1990). Laboratory study of the spawning rate of the calanoid Centropages typicus: effect of fluctuating food concentration. J. Plankton Res. 12: 535-547

Paffenhöfer, G.-A. (1976). Feeding, growth, and food conversion of the marine planktonic copepod Calanus helgolandicus. Limnol. Oceanogr. 21: 39-50

Paffenhöfer, G.-A. (1993). On the ecology of marine cyclopoid copepods (Crustacea, Copepoda, Cyclopoida). J. Plankton Res. 15: 37--55

Paffenhöfer, G.-A., Harris, R. P. (1976). Feeding, growth and reproduction of the marine planktonic copepod Pseudocalanus elongatus Boeck. J. mar. biol. Ass. U.K. 56: 327-344

Park, C., Landry, M. R. (1993). Egg production in the subtropical copepod Undinula vulgaris. Mar. Biol. 117: 415-421

Peterson, W. T. (1986). Development, growth, and survivorship of the copepod Calanus marshallae in the laboratory. Mar. Ecol. Prog. Ser. 29: 61-72

Peterson, W. T (1988), Rates of egg production by the copepod Calanus marshallae in the laboratory and in the sea off Oregon, USA. Mar. Ecol. Prog. Ser. 47: 229-237

Peterson, W. T., Painting, S. (1990). Developmental rates of the copepods Calanus australis and Calanoides carinatus in the laboratory, with discussion of methods used for caiculation of development time. J. Plankton Res. 12: 283-293

Razouls, S., Razouls, C.. Huntley, M. (1991). Development and expression of sexual maturity in female Calanus pacificus (Copepoda: Calanoida) in relation to food quality. Mar. Biol 110: $65-74$

Runge, J. A. (1984). Egg production of the marne, planktonic copepod, Calanus pacificus Brodsky: laboratory observations. J. exp. mar. Biol. Ecol. 74: 53-66

Sabatini, M., Kiorboe, T (1994). Egg production, growth and development of the cyclopold copepod Oithona similis. $J$. Plankton Res. 16: 1329-1351

Sekiguchı, H., McLaren, I. A., Corkett, C J. (1980). Relatıonship between growth rate and egg production in the copepod Acartia clausi hudsonica. Mar. Biol. 58: 133-138

Senjie, L., Song, L. (1989). Food effect on egg production rate and in situ reproductive characteristics of Labidocera euchaeta Giebrescht. J. Xiamen Univ. (Natural Sclence) 28: 203-207 (in Chinese with English abstract)
Senjie, L., Song, L. (1990a). Development rate of Labidocera euchaeta Giebrescht in Xiamen Harbor. Acta Oceanologica Sinica 9: 439-447

Senjie, L., Song, L. (1990b). Growth rate of Labidocera euchaeta Giebrescht in Xiamen Harbor, Fujian. J. Oceanogr. Talwan Strat 9: 48-55 (in Chinese with English abstract)

Shaojing, L., Feng, C., Guizhong, W. (1989). Studies on the feature of eggs and its hatching rates of some planktonic copepods in Xiamen waters. J. Xiamen Univ. (Natural Science) 28: 538-543 (in Chinese with English abstract)

Smith, S. L. (1990). Egg production and feeding by copepods prior to the spring bloom of phytoplankton in Fram Strait, Greenland Sea. Mar. Biol. 106: 59-69

Smith, S. L., Lane, P. V. Z. (1985). Laboratory studies of the marine copepod Centropages typicus: egg production and development rates. Mar. Biol. 85: 153-162

Thompson, B. M. (1982). Growth and development of Pseudocalanus elongatus and Calanus sp. in the laboratory. J. mar. biol. Ass. U.K. 62: 359-372

Tiselius, P., Berggreen, U., Båmstedt, U., Hansen, B., Kiørboe, T., Mohlenberg, F. (1987). Ecological and physiological aspects of propagation in marina herbivorous copepods (A prelıminary report). Report of the Marine Pollut. Lab., Charlottenlund

Trujillo Ortiz, A. (1990). Hatching success, egg production and development time of Acartia californiensis Trinast (Copepoda Calanoida) under laboratory conditions. Cienc. Mar. Ensenada 16: 1-22

Uchima, M. (1979). Morphological observation of developmental stages in Oithona brevicornis (Copepoda, Cyclopoida). Bull. Plankton Soc. Jap. 26: 59-76

Uye, S.-I. (1981). Fecundity studies of neritic calanoid copepods Acartia clausi and A. stueri Sminnov: a simple empirical model of daily egg production. J. exp. mar. Biol. Ecol. 50: $255-271$

Uye, S.-I. (1988). Temperature-dependent development and growth of Calanus sinicus (Copepoda: Calanoida) in the laboratory. Hydrobiologia 167/168: 385-293

Uye, S.-I. (1991). Temperature-dependent development and growth of the planktonic copepod Paracalanus sp. in the laboratory. Proc. 4th Int. Conf. on Copepoda. Bull. Plankton Soc Jap., Spec. Vol.: 627-636

Uye, S.-I., Iwai, Y., Kasahara, S. (1983). Growth and production of the inshore marine copepod Pseudodiaptomus marinus in the central part of the Inland Sea of Jap. Mar. Biol. 73: 91-98

Uye, S.-I., Onbé, T. (1975). The developmental stages of Pseudiaptomus maninus Sato (Copepoda, Calanoida) reared in the laboratory. Bull. Plankton Soc. Jap. 21: $65-76$

Uye, S.-I., Shibuno, N. (1992). Reproductive biology of the planktonic copepod Paracalanus sp. in the Inland Sea of Japan. J. Plankton Res. 14: 343-358

Vidal, J. (1980a). Physioecology of zooplankton. I. Effects of phytoplankton concentration, temperature, and body size on the growth rate of Calanus pacificus and Pseudocalanus sp. Mar. Biol. 56: 111-134

Vidal, J. (1980b) Physioecology of zooplankton. II. Effects of phytoplankton concentration, temperature, and body size on the development and moulting rates of Calanus pacificus and Pseudocalanus sp. Mar. Biol. 56: 135-146

Vidal, J., Smith, S. L. (1986). Biomass, growth and development of populations of herbivorous zooplankton in the southeastern Benng Sea during spring. Deep Sea Res. 33: 523-556

Vifela, M. H. (1972). The developmental stages of the marine calanoid copepod Acartia grani Sars bred in the laboratory. Not Estud Inst. Biol. Marit., Lisboa 40: 1-20

Zurlinl, G., Ferrari, I., Nasogne, A. (1978). Reproduction and growth of Euterpina acutifrons (Copepoda, Harpacticoida) under experimental conditions. Mar. Biol. 46: 59-64 